\title{
Diplopia in a patient with chronic rhinosinusitis: think about the orbit
}

\author{
Khizar Rana, ${ }^{1,2}$ Valerie Juniat, ${ }^{1,2}$ Dinesh Selva, ${ }^{1,2}$ Alkis J Psaltis ${ }^{3,4}$
}

${ }^{1}$ Discipline of Ophthalmology and Visual Sciences, The University of Adelaide, Adelaide, South Australia, Australia ${ }^{2}$ South Australian Institute of Ophthalmology, Adelaide, South Australia, Australia

${ }^{3}$ Department of Otolaryngology Head and Neck Surgery, Queen Elizabeth Hospital, Woodville, South Australia, Australia

${ }^{4}$ Faculty of Health and Medical Sciences, The University of Adelaide, Adelaide, South Australia, Australia

\section{Correspondence to}

Khizar Rana;

khizar.rana@student.adelaide. edu.au

Accepted 30 December 2020

\section{DESCRIPTION}

A 72-year-old male patient was seen in ear, nose and throat (ENT) clinic with chronic rhinosinusitis and diplopia. He had previously undergone partial ethmoidectomy and maxillary antrostomies for sinus issues 6 years ago. One month prior to this visit, he had developed right nasal congestion, maxillary pressure, epistaxis, some limitation of right upgaze with diplopia but with normal vision. There was no pain, proptosis or findings of cranial nerve palsies that would be in keeping with an orbital apex syndrome. He was diagnosed and treated elsewhere with sinusitis-related diplopia. The diplopia subjectively improved on intravenous dexamethasone and oral antibiotics but recurred on stopping the steroids.

Nasal endoscopy showed scarring in keeping with previous surgery but there was no evidence of any masses. CT scan carried out prior to steroid treatment was reviewed and showed opacification of his maxillary sinuses, right ethmoid and sphenoid sinus (figure 1A). An orbital apex lesion (arrow) was subsequently noted adjacent to the sinus opacification. MRI carried out after the ENT appointment confirmed the subtle right orbital apex lesion with infiltration through the medial wall of the apex (figure 1B). The skull base appeared intact with no obvious tumour involvement or breach. The lesion had not changed significantly radiologically following steroid treatment, and the decision was made to biopsy the lesion.

The patient had sinus exploration as a joint case with an ENT and orbital surgeon. Intraoperatively, the area of mucosal thickening noted on imaging appeared unremarkable and biopsies taken of the right sphenoid mucosa, right posterior ethmoid mucosa and right maxillary sinus did not show any histopathological evidence of tumour. Further exploration was continued with removal of the lamina papyracea to obtain a biopsy from the

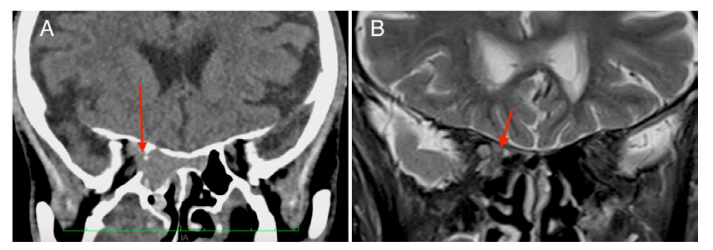

Limited 2021. No commercial re-use. See rights and permissions. Published by BMJ.

To cite: Rana $K_{\text {, Juniat } V_{\text {, }}}$ Selva $\mathrm{D}$, et al. BMJ Case Rep 2021;14:e240127. doi:10.1136/bcr-2020240127
Figure 1 (A) CT showing an isodense right orbital lesion (arrow) that was initially missed due to the adjacent sinus disease. (B) MRI (T2 fat-suppressed coronal sequence) of the orbit showing an isointense right orbital apex lesion (arrow) with infiltration of the medial apex wall. Note: There were no MRI axial images available.

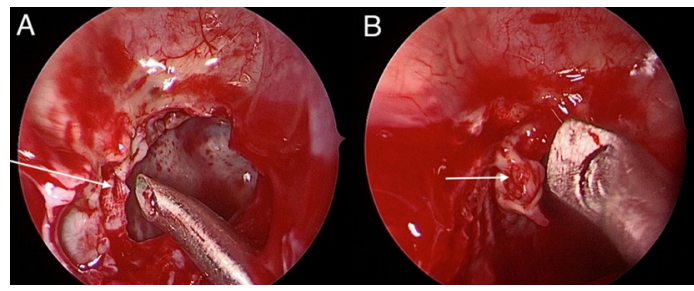

Figure 2 (A) Intraoperative image of the right orbital apex showing an area of abnormal mucosa (arrow). (B) A biopsy of this lesion (arrow) was taken and reported as a lymphoma.

suspicious area on imaging. Examination of the exposed right orbital apex revealed an abnormal area, which appeared thickened and grey compared with the surrounding tissue (figure 2). Biopsy of this region revealed diffuse large B cell lymphoma, which was positive for CD-20, BCL-6 (B-cell lymphoma 6 protein) and CD10 on flow cytometry.

A number of ENT conditions including primary malignancy, trauma, autoimmune conditions, silent sinus syndrome and infections can present with diplopia. ${ }^{1}$ Sphenoid sinusitis can present with diplopia secondary to ocular cranial nerve involvement. ${ }^{2}$ The abducens nerve is most commonly affected due to its medial location within the cavernous sinus and proximity to the sphenoid sinus. Antibiotic therapy along with surgical drainage can result in complete recovery of the diplopia in most cases. ${ }^{2}$

Alternative causes of diplopia should be sought for in patients with persistent diplopia after resolution of the acute sinusitis. MRI of the orbit is essential for delineating soft tissues and masses within this region. CT may miss orbital lesions particularly in the presence of significant adjacent sinus disease as seen in our patient.

Lymphoma is the the most common cause of adult orbital tumours. ${ }^{3}$ Patients usually present in an indolent fashion, with a slowly progressive history of proptosis, palpable mass or lid swelling. Less commonly, patients present with functional symptoms such as diplopia and/or vision change. Orbital lymphoma involving the orbital apex may spread to the adjacent sinuses presenting to ENT with symptoms such as nasal blockage or epistaxis. ${ }^{34}$ Diffusion-weighted MRI can help differentiate malignant lesions such as orbital lymphoma from benign lesions. ${ }^{5-7}$ Steroids can reduce tumourrelated oedema and have a direct lympholytic effect on the lymphoma, helping to temporarily improve visual function. ${ }^{8}$ Early diagnosis prior to local and 
systemic dissemination helps to direct patient management and improve survival rates. ${ }^{3}$

\section{Learning points}

- Persistent diplopia in a patient with chronic rhinosinusitis may be due to an orbital lesion.

- Orbital lymphoma may involve the orbital apex and spread to the adjacent sinuses presenting to ear, nose and throat (ENT) with symptoms such as nasal blockage or epistaxis.

- MRI of the orbit is essential for delineating soft tissues and masses within this region, especially in patients who may have concurrent sinus disease.

Contributors DS and AJP participated in diagnosis and treatment of the patient. $\mathrm{KR}$ and VJ participated in preparing the manuscript and finalising it under DS and AJP guidance.

Funding The authors have not declared a specific grant for this research from any funding agency in the public, commercial or not-for-profit sectors.
Competing interests None declared.

Patient consent for publication Obtained.

Provenance and peer review Not commissioned; externally peer reviewed.

\section{REFERENCES}

1 Muneer A, Jones NS, Bradley PJ, et al. Ent pathology and diplopia. Eye 1998;12 (Pt 4:672-8.

2 El Mograbi A, Soudry E. Ocular cranial nerve palsies secondary to sphenoid sinusitis. World J Otorhinolaryngol Head Neck Surg 2017;3:49-53.

3 Olsen TG, Heegaard S. Orbital lymphoma. Surv Ophthalmol 2019;64:45-66.

4 Parikh VS, Jagadeesh D, Fernandez JM, et al. Orbital diffuse large B-cell lymphoma with combined variable immunodeficiency. Orbit 2017;36:340-3.

5 Eissa L, Abdel Razek AAK, Helmy E. Arterial spin labeling and diffusion-weighted MR imaging: utility in differentiating idiopathic orbital inflammatory pseudotumor from orbital lymphoma. Clin Imaging 2020;71:63-8.

6 Razek AAKA, Sieza S, Maha B. Assessment of nasal and paranasal sinus masses by diffusion-weighted MR imaging. J Neuroradiol 2009;36:206-11.

7 Abdel Razek A, Mossad A, Ghonim M. Role of diffusion-weighted MR imaging in assessing malignant versus benign skull-base lesions. Radiol Med 2011;116:125-32.

8 Ezdinli EZ, Stutzman L, Aungst CW, et al. Corticosteroid therapy for lymphomas and chronic lymphocytic leukemia. Cancer 1969;23:900-9.

Copyright 2021 BMJ Publishing Group. All rights reserved. For permission to reuse any of this content visit

https://www.bmj.com/company/products-services/rights-and-licensing/permissions/

BMJ Case Report Fellows may re-use this article for personal use and teaching without any further permission.

Become a Fellow of BMJ Case Reports today and you can:

- Submit as many cases as you like

- Enjoy fast sympathetic peer review and rapid publication of accepted articles

- Access all the published articles

Re-use any of the published material for personal use and teaching without further permission

\section{Customer Service}

If you have any further queries about your subscription, please contact our customer services team on +44 (0) 2071111105 or via email at support@bmj.com.

Visit casereports.bmj.com for more articles like this and to become a Fellow 